\title{
Determinants of Small and Medium Size Enterprises Access to Credit Schemes in the Mezam Division of Cameroon
}

\author{
Ngoe Mukete ${ }^{*}$, Zhou Li' ${ }^{1}$, Beckline Mukete ${ }^{2}$, Namondo Irene ${ }^{3}$, Aminkeng Terence ${ }^{4}$, \\ Coulibaly Abdoulaye ${ }^{5}$, Kossi Fandjinou6, Romeo Ekoungoulou7, Fousseni Folega8, \\ Sajjad Saeed ${ }^{2}$, Patrick Amah", Eric Zama10
}

${ }^{1}$ College of Economics and Management, Nanjing Agricultural University, Nanjing, China

${ }^{2}$ School of Forestry, Beijing Forestry University, Beijing, China

${ }^{3}$ Higher Technical Teachers Training College, University of Bamenda, Bambili, Cameroon

${ }^{4}$ School of Economics and Management, Nanjing University of Science and Technology, Nanjing, China

${ }^{5}$ School of Economics and Management, Beihang University, Beijing, China

${ }^{6}$ School of Soil and Water Conservation, Beijing Forestry University, Beijing, China

${ }^{7}$ Ecole Nationale Supérieure d'Agronomie et Foresterie, Université Marien Ngouabi, Brazzaville, Congo

${ }^{8}$ Laboratoire de Botanique et d'Ecologie Végétale, Université de Lomé, Lomé, Togo

${ }^{9}$ Department of Lifelong Education, Hanseo University, Seosan, South Korea

${ }^{10}$ College of Technology, University of Bamenda, Bafut, Cameroon

Email: ^ngoer@yahoo.com, zhouli@njau.edu.cn, munasawa@gmail.com, imukete04@yahoo.com, aminkengterence@yahoo.com, fandnew@yahoo.fr, romeoekous@gmail.com, abdoulayesodiani@yahoo.fr, sajjad_saeed222@yahoo.com, ffolegamez@live.fr, amahpat@yahoo.com, ericzama@gmail.com

How to cite this paper: Mukete, N., Li, Z., Mukete, B., Irene, N., Terence, A., Abdoulaye, C., Fandjinou, K., Ekoungoulou, R., Folega, F., Saeed, S., Amah, P. and Zama, E. (2021) Determinants of Small and Medium Size Enterprises Access to Credit Schemes in the Mezam Division of Cameroon. Open Access Library Journal, 8: e7079.

https://doi.org/10.4236/oalib.1107079

Received: December 14, 2020

Accepted: February 1, 2021

Published: February 4, 2021

\begin{abstract}
Promoting small and medium size enterprises is a governmental strategy aimed at achieving national economic development through poverty alleviation, employment creation and other income generation activities. This study examined the determinants of small and medium size enterprises access to credit schemes around Mezam Division located in the North West Region of Cameroon. A two-stage sampling technique was used to obtain data from over 294 enterprises. Descriptive statistics and logit regression analysis were used to analyze the data. Results revealed that $5.8 \%$ of the small and medium size enterprises had accessed bank credit only while $92.2 \%$ obtained finance from informal credit sources. The logit analysis indicated that access to formal credit was determined by the educational level of the enterprise owner or manager, longevity in business, and the availability of collateral security. Government policies with respect to credit access by enterprises should be involved and begin from both lenders and creditors.
\end{abstract}


Copyright $\odot 2021$ by author(s) and Open Access Library Inc.

This work is licensed under the Creative Commons Attribution International License (CC BY 4.0).

http://creativecommons.org/licenses/by/4.0/

\section{Subject Areas}

Accounting, Business Analysis, Business Communication, Business Finance and Investment, Business and Economics Education, Monetary Economics

\section{Keywords}

Small and Medium-Size Enterprises, Access to Finance, Regression Model, Cameroon, Mezam Division

\section{Introduction}

Across the globe, small and medium size enterprises (SMEs) substantially contribute to the national economy through tax returns and employment creation [1] [2] [3]. According to [4] [5], globally SMEs account for over $85 \%$ of firms representing about $66 \%$ of non-farm employment opportunities and Gross Domestic Product (GDP). In a related study, [2] and [6] observed SMEs to make up a dominant share of private sector activity in most less developed countries. For instance, in Africa SMEs are estimated to make up about $80 \%$ of firms and which employ over $70 \%$ of the local population while contributing to an estimated $45 \%$ of the total GDP [7] [8].

The classification of SMEs differs from one country to another and it is based on their role within the economy, policies and programs. These programs are designed by specific agencies and institutions which develop, regulate and empower the various SMEs. From these perspectives, in the United States of America, an SME refers to a firm with total assets of less than US\$9 [9]. Meanwhile within the European Union, SMEs are often small business ventures employing less than 50 individuals and having annual sales of less than 10 million Euros [10]. On the other hand, in Cameroon, according to Law Number 2010/001 of April 13, 2010, an SME belongs to a set of Very Small Enterprises employing less than 5 people and with an annual revenue of about 25,000 Euros or 15 million FCFA. In addition, small firms are Very Small Enterprises employing between 6 20 people and having an annual financial turnover of between 25,000 and 175,000 Euros [11].

In Cameroon, SMEs are included in the country's growth and employment strategy paper (GESP) [12]. These SMEs involve over $90 \%$ of the country's economic sector while contributing an estimated $36 \%$ of the national GDP [11]. In a similar study, [13] found SMEs in Cameroon to contribute over $30 \%$ of the local government taxes. Despite being a major driver in economic growth, infrastructure development and source of employment, SME survival and growth in Cameroon and elsewhere across the African continent are heavily challenged.

Several studies have shown this challenge to be mainly related to accessibility to financial schemes [14] [15] [16] [17]. In another study conducted by the World Bank in 2015, an estimated 70\% of all SMEs in developing market econ- 
omies were found to lack access to finance. In Cameroon for instance, [18] observed that formal access to credit by SMEs is extremely limited. Furthermore, penetration by banks into the private sector is very low across the country thus the required credit to SMEs is not provided. The various SMEs are therefore compelled to rely on personal assets, family and friends for capital investments hence limiting operations in full capacity (increase output and sales).

Access to credit often refers to the possibility for individuals, enterprises, groups, organizations as well as governments to access financial services. These services may include credits, deposits, payments, insurances, and other risk management services at affordable costs [19]. The acquisition of finance increases, facilitates and enhances the development and improvement of SME products and services. In another study, [20] showed credit access to facilitate the utilization of productive assets to enhance productivity and economy of scale. A related study conducted by [21], posited the availability of external finance to directly impact productivity and growth of SMEs particularly in developing economies [21]. From a global perspective, banks remain the major external provider of capital to SMEs in both developed and developing countries [1] [22]. Therefore, enhancing access to finance for SMEs may increase income levels, employment and thereby alleviating poverty.

For several decades, access to credit by SMEs has drawn the worldwide attention of academicians and policy makers. As a result, several studies have examined the determinants of access to finance by SMEs. For instance, in South Africa, [23] using Pearson correlation and logistic regression showed collateral (personal or business property), business information, experience (longevity in business), employment structure and location of the SME to influence access to finance by SMEs. Similarly, in Tanzania, [20] indicated that a firm's location, size, business information, age, incorporation and collateral influenced its access to credit.

Elsewhere in Bangladesh [19] observed firm size and age, education and skills of the owners, and unfavorable credit terms such as high interest rates, lack of collateral security, corruption to hinder SME access to finance. According to [24], collateral requirement is the main factor affecting SME access to credit in Kenya. In another study conducted around the Maputo central business district of Mozambique, [25] found banking systems and regulatory structures to impede SMEs access to finance. Similarly, [5] posited that factors such as owner or manager character, capacity, firm capital size, credit bureau report with the availability and credibility of financial statements-controlled SMEs access to credit in Egypt.

Using Probit regression, [18] found interest rates, size of enterprise, size of loan, size of collateral, maturity of loans and legal status of enterprises to be the major factors affecting SMEs access to finance in Cameroon. Their study also revealed medium enterprises to be more credit constrained than small enterprises while credit constraints affect small enterprises more than medium size enterprises. In a related study conducted in Cameroon, [26] found SMEs to face 
many obstacles that prevent them from growing including access to finance and the cost of financing are in the top three constraints.

The present study therefore, seeks to add to the existing knowledge on the constraints faced by SME to access credit and fill that knowledge-gap. This is performed through an analysis of the determinants of SMEs access to credits in the Mezam Division located in the North West Region of Cameroon. The research findings may assist policy makers in implementing proper development assistance for SMEs, particularly their access to finance within the study area and Cameroon in general.

\section{Research Methodology}

\subsection{Description of the Study Area}

This study was carried out around Mezam Division located in the North West Region of Cameroon. The division is one of the seven divisions of the region covering an estimated total surface area of $1745 \mathrm{~km}^{2}$ and population of over 524,127 inhabitants. Located between latitudes $5^{\circ} 40^{\prime}$ and $7^{\circ} 50^{\prime}$ North and longitudes $9^{\circ} 80^{\prime}$ and $11^{\circ} 51^{\prime}$ East, it consists of seven sub divisions which include Bamenda 1, Bamenda 2, Bamenda 3, Bafut, Bali, Santa, and Tubah Subdivisions [27]. The division is bounded by Menchum, Boyo and Momo divisions to the North and East, and the Western region to the South and West, Figure 1.

The division is made up of both rural, semi-urban and urban areas. The rural settlements are sparsely populated and where the local inhabitants are mostly involved in subsistence and plantation agriculture. Meanwhile, in the semi-urban and urban areas, the local population is involved in agriculture, manufacturing and other tertiary activities [28] [29]. The division exhibits a cool temperate-like climate, influenced mainly by mountainous terrain and rugged topography. Average rainfall is about $2400 \mathrm{~mm}$ with an average temperature between $15^{\circ} \mathrm{C}-32^{\circ} \mathrm{C}$. There are two main seasons which are the rainy season from March to October and the dry season from November to February [30] [31].

\subsection{Data Collection}

This study was carried out between March 2019 and January 2020 using a simple random sampling method. Specific firms which had been operating within the previous three years prior to this study were identified for the focus group discussions and individual questionnaires as described by [32]. Data were collected from individuals involved with SMEs about their demographic characteristics, sector of activity, longevity in business, availability of business plan, other sources of finance, employment structure, business registration certificate, and access to credit about the SMEs. 294 individuals were surveyed and site selection was based on geographical location which was the Mezam division.

In towns such as Bamenda, Bali, Nkwen, Bambili, Bambui and Santa, with a respondent population of more than one hundred, the town was divided into 


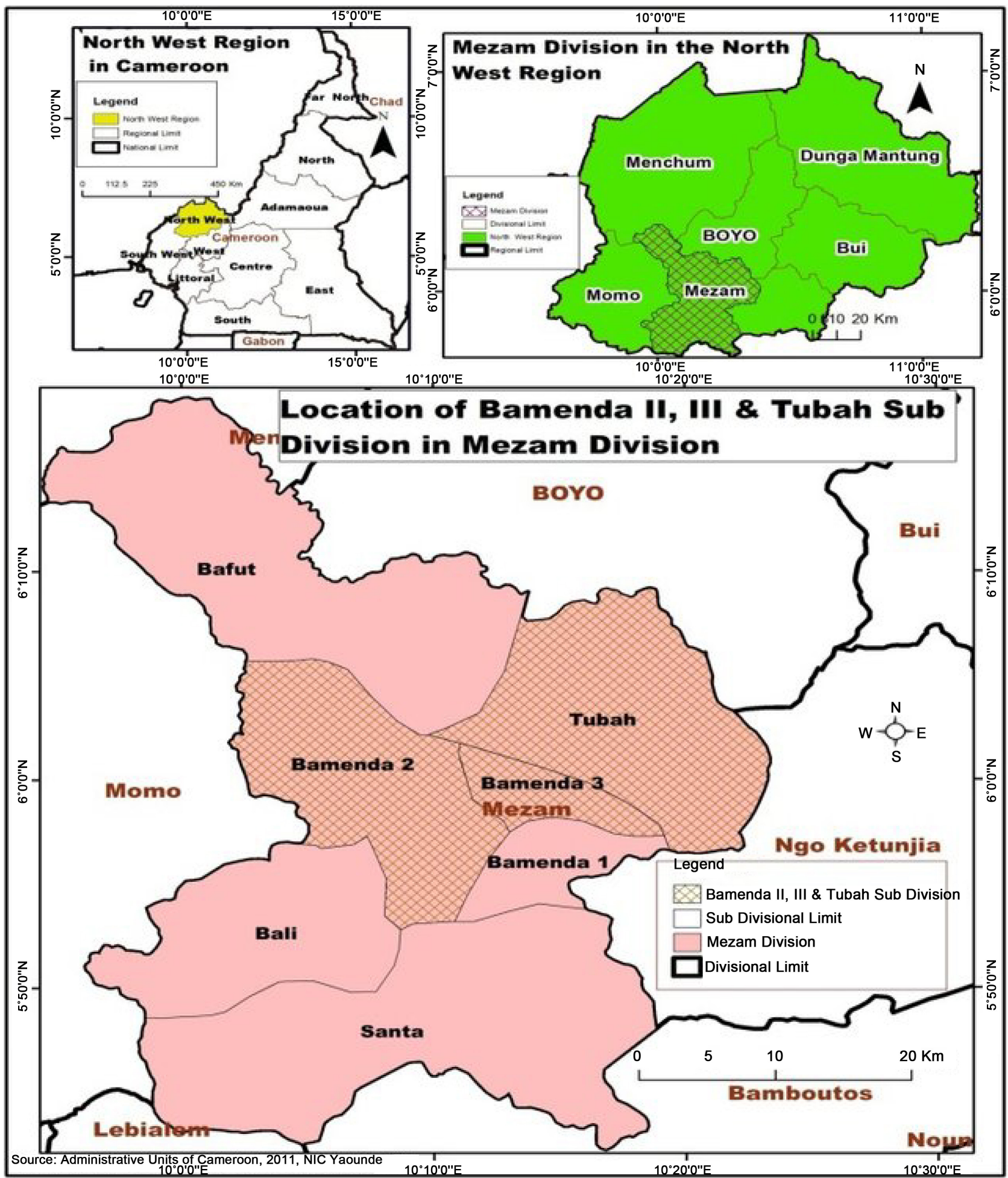

Figure 1. Map of the mezam division in the northwest region of cameroon. Source: [28].

quarters for the focus group discussions which was made up of about ten respondents of at least 18 years old (as required by Cameroon Law). A verification of their National Identity Cards was performed and in cases where this was unavailable, recommendation was sought from the local community leader. In 
towns such as Bafut, Akum, Chomba, Mendankwe, Mbatu, Awing and Pinyin with a respondent population of less than one hundred, only the semi-structured and open-ended questionnaires through a door-to-door survey were used. In instances were potential participants were unable to read and understand the English or French languages, the local Pidgin English was used to ensure proper understanding according to [32].

Simple random sampling method is part of triangulation which involves selecting from different methods based on their individual compatibility and strengths. Furthermore, triangulation looks at issues which stem from construct validity as a result of the fact that, the diverse sources of evidence essentially provide complex measures of a similar situation [32].

\subsection{Data Analysis and Model Specification}

Descriptive statistics used to analyze the data included the use of frequencies and percentages. Stata version 13.0 was used for the logit regression model analysis such as to identify determinants of SMEs access to credit. The logit model was employed because it considers the relationship between a binary dependent variable and a set of independent variables, be they binary or continuous according to [31] [33].

For this study, the logit model is given in Equation (1).

$$
\begin{aligned}
\text { Credit }_{i}= & \beta_{0}+\beta_{1} \text { Age }_{i}+\beta_{2} \text { Educ }_{i}+\beta_{3} \text { Gender }_{i}+\beta_{4} \text { Mstatus }_{i} \\
& +\beta_{5} \mathrm{SA}_{i}+\beta_{6} \operatorname{Exp}_{i}+\beta_{7} \text { Bizp }_{i}+\beta_{8} \text { CollSec }_{i}+\varepsilon_{i}
\end{aligned}
$$

where, Credit is the dependent variable (Access to credit), $\beta_{0}=$ Constant term, Age $=$ Age of the business owner or manager, Educ $=$ Level of education of the owner/manager, Gender $=$ Gender of the respondent, Mstatus = Marital status, $\mathrm{SA}=$ Sector of activity, Exp = Longevity measured by the number of years the business has been operating, Bizp = Business plan availability, CollSec represents lack of collateral security and $\varepsilon_{i}=$ Error term.

\section{Results}

\subsection{Characteristics of Respondents}

$69.4 \%$ of the respondents were males and $30.6 \%$ females. Meanwhile, $22.4 \%$ were aged 21 - 30 years, $44.9 \%$ between 31 - 40 years and $32.7 \%$ were over 41 years. Also, $22.8 \%$ had no education, $15.3 \%$ had primary education while only $27.3 \%$ and $34.7 \%$ had respectively attained secondary and university education, Table 1.

\subsection{Characteristics of SMEs}

36.1\% of the SMEs have been in operation for less than 5 years, 37.4\% between 5 10 years and $26.5 \%$ for 10 years and above. About $55.4 \%$ of the SMEs were involved in trading, $12 \%$ in manufacturing, $24.1 \%$ in service provision and $8.5 \%$ in agriculture, Table 2 . Similarly, $77.9 \%$ of the SMEs were duly registered with the government of Cameroon while $22.1 \%$ were unregistered. Furthermore, $48.6 \%$ 
Table 1. Descriptive statistics of SME owner characteristics.

\begin{tabular}{ccc}
\hline Variable & Frequency & Percentage \\
\hline Gender & 204 & 69.4 \\
Male & 90 & 30.6 \\
Female & & \\
Age & 66 & 22.4 \\
$21-30$ & 132 & 44.9 \\
$31-40$ & 96 & 32.7 \\
Above 41 & & \\
Educational level & 67 & 22.8 \\
No education & 45 & 15.3 \\
Primary & 80 & 27.2 \\
Secondary & 102 & 34.7 \\
University & & \\
Marital status & 134 & 45.6 \\
Married & 76 & 25.9 \\
Single & 46 & 15.6 \\
Divorced & 38 & 12.9 \\
Widowed & & \\
\hline
\end{tabular}

Table 2. Characteristics of SMEs.

\begin{tabular}{|c|c|c|}
\hline Variable & Frequency & Percentage \\
\hline \multicolumn{3}{|c|}{ Longevity in business (years) } \\
\hline $0-4$ & 106 & 36.1 \\
\hline $5-9$ & 110 & 37.4 \\
\hline Above 10 & 78 & 26.5 \\
\hline \multicolumn{3}{|l|}{ Sector of activity } \\
\hline Trading & 163 & 55.4 \\
\hline Manufacturing & 35 & 12.0 \\
\hline Service provision & 7 & 24.1 \\
\hline Agriculture & 25 & 8.5 \\
\hline \multicolumn{3}{|l|}{ Registration of business } \\
\hline Yes & 229 & 77.9 \\
\hline No & 65 & 22.1 \\
\hline \multicolumn{3}{|l|}{ Number of employees } \\
\hline $0-5$ & 143 & 48.6 \\
\hline $6-11$ & 126 & 42.9 \\
\hline $12-17$ & 18 & 6.1 \\
\hline Above 18 & 7 & 2.4 \\
\hline \multicolumn{3}{|c|}{ Availability of business plan } \\
\hline Yes & 221 & 75.2 \\
\hline No & 73 & 24.8 \\
\hline \multicolumn{3}{|c|}{ Collateral security availability } \\
\hline Yes & 104 & 35.4 \\
\hline No & 190 & 64.6 \\
\hline \multicolumn{3}{|l|}{ Access to credit } \\
\hline Personal savings & 107 & 36.4 \\
\hline Bank credit/loans & 17 & 5.8 \\
\hline Family and friends & 93 & 31.6 \\
\hline Njangi houses & 77 & 26.2 \\
\hline
\end{tabular}


of the enterprises had less than 5 employees, $42.9 \%$ between 6 and 11 employees, 6.1\% from $12-17$ employees and $2.4 \%$ had 18 employees and above. On the other hand, only $5.8 \%$ of the SMEs had access to bank credit while $92.2 \%$ had access to informal credit sources such as personal savings, borrowing from family and friends.

\subsection{Determinants of Access to Credit}

The Logistic regression shows a negative coefficient for level of the enterprise owner or manager. This suggests that a $1 \%$ increase in the level of education decreases the probability of an enterprise being credit constrained. Similarly, the coefficient of longevity in business shows a negative coefficient and significance at $1 \%$ level. This indicates that the likelihood of an SME being credit constrained reduces with longevity in business. Moreover, the negative coefficient of the availability of collateral security shows the chances to be denied a loan reduces with collateral security, Table 3 .

\section{Discussion}

Educated owners especially those with a university education, stand a better chance of credit access. This may be because the more educated an individual is, the more his or her level of awareness, exposure and access to business related information. The individual is also able to prepare access to credit related documentation including financial statements and records of business transactions. In a related study, [19] posited that educated entrepreneurs had skills which enabled them build up more solid relationships with the financial institutions. These solid relationships eased their access to credit and created platforms which facilitated their adequate management of credit destined for various business purposes. Hence, the longer an enterprise has stayed in business, the higher its chances of obtaining credit from a bank. This longevity provides for an asset base on which banks may judge as collateral in processing the SME's request for credit.

Table 3. Logit regression of determinants of SME access to credit.

\begin{tabular}{|c|c|c|c|c|}
\hline Variables & Coefficients & $\begin{array}{c}\text { Standard. } \\
\text { Error }\end{array}$ & t-statistic & $\mathrm{P}>|\mathrm{z}|$ \\
\hline Age (years) & $-5.317^{\star * *}$ & 0.968 & -5.49 & 0.000 \\
\hline Gender $($ male $=1$, female $=0)$ & $3.085^{\star * *}$ & 0.840 & 3.67 & 0.000 \\
\hline Level of education & $-2.222^{\star * \star}$ & 0.497 & -4.47 & 0.000 \\
\hline Marital status & $7.056^{* * *}$ & 1.913 & 3.69 & 0.000 \\
\hline Longevity in business (years) & $-2.055^{\star * *}$ & 0.627 & -3.28 & 0.001 \\
\hline Availability of business plan (yes $=1$ ) & $-9.542^{\star * *}$ & 1.734 & -5.50 & 0.000 \\
\hline Availability of collateral security (yes $=1$ ) & $-1.313^{* * *}$ & 0.431 & -3.05 & 0.002 \\
\hline Registration of business (yes $=1$ ) & $-8.449^{* * *}$ & 1.864 & -4.53 & 0.000 \\
\hline Constant & $44.041^{* * *}$ & 7.789 & 5.65 & 0.000 \\
\hline
\end{tabular}

$* * *, * *,{ }^{*}$ indicate significance of estimated coefficient at $1 \%, 5 \%, 10 \%$ levels of probability respectively. 
According to [20], longevity in business was a major factor which determined access to credit by small and medium-sized enterprises across Tanzania. In a similar study conducted in Botswana, [34] found a firm owner's experience to increase the likelihood of the firm's access to credit from a bank. Meanwhile in Cameroon, [18] observed older SMEs with a business history of greater than 5 years, had very little or no influence on the probability of being credit constrained. From another perspective and such as to curb default risks, collateral security is often one of the measures demanded by banks to grant loans to SMEs. The collateral is negatively related to the probability of the enterprise being credit constrained and an SME can therefore borrow when in possession of substantial collateral. A similar study carried-out in Malaysia by [35] found collateral to have a significant effect on the likelihood of loan approval by financial institutions.

Several shortcomings were encountered in this study such as the difficulties in obtaining up-to-date information due to the lack of scientific literatures from the study area. There are little field studies which could be used to evaluate and quantify the SME sector across the study area and Cameroon in general. Therefore, additional research work is required such as to corroborate and provide qualitative and quantitative information relating to SMEs. Areas of further studies could examine how the government of Cameroon is encouraging the SME sector and how this impacts on the nation's economy. Also, the sociopolitical determinants which influence the expansion of SMEs in the northwest region could also be studied.

\section{Conclusions}

Credit constraints operate in a variety of ways in Cameroon where an underdeveloped state of capital markets causes enterprises to rely on informal credit sources. This study examined the determinants of small and medium size enterprises access to credit schemes in the Mezam division of Cameroon. The results pointed out that $5.2 \%$ of the SMEs accessed credit from banks while $92.8 \%$ obtained finance from informal credit sources. The logit model results showed that the educational level of the enterprise owner or manager, longevity in business, and the availability of collateral security determines SME's access to credit from financial institutions.

Therefore, financial and government institutions should expand their financial support to the small business sector it being a major force in the country's economic sphere. Through various legislative mechanisms, governments can provide financial, operational, business and marketing support to SMEs. These may involve the provision of collateral while creating and also supporting various loan schemes undertaken by SMEs. These loan schemes could also involve mechanisms which encourage SMEs to hire more personnel, achieve financial autonomy and a reduction in government or local taxes. Such as to reduce the financial burden on SMEs and increase efficiency or productivity, governments 
could also subsidize the training of SME personnel.

Furthermore, governments could cover or subsidize the cost of business or marketing consulting for SMEs. From this perspective, the government of Cameroon could aid in organizing through subsidies, the SME conferences, events such as trade fairs, road shows which may increase awareness and networking for local SMEs. These events would facilitate the participation of SMEs at lower expense thus helping these SMEs in attracting new customers and opening up to other business ventures as well as partners.

This may help the sector to continue reducing the effect of socio-economic challenges like unemployment, inequality and poverty. Also, financial institutions should be involved in creating awareness, particularly the importance of collateral through advertisements, communication with trade associations and business related events including trade fairs. The SME may become aware of requirements which would thus encourage investment in collateral assets.

\section{Conflicts of Interest}

The authors declare no conflicts of interest regarding the publication of this paper.

\section{References}

[1] World Bank. (2014) Doing Business 2014: Understanding Regulations for Small and Medium-Size Enterprises. Washington DC, World Bank Group. https://openknowledge.worldbank.org/handle/10986/16204

[2] Diallo, A., Yin, Z and Mukete, B (2017) Assessing the Socioeconomic Impacts of the Informal Sector in Guinea, West Africa. Open Access Library Journal, 4, e3290.

[3] Diakite, B., Jian, B., Mukete, B., Duyile, L., Kang, K. and Bakia, S. (2020) Trends, Opportunities and Challenges of the Tourism Industry in the Republic of Guinea. Social and Economic Geography, 5, 7-14.

[4] Mutiria, M. (2017) Factors Influencing Small and Medium Size Enterprises Access to Financing: A Case of Kiambu County, Kenya. MBA Dissertation, United States International University, Nairobi.

[5] Boushnak, E., Rageb, A., Ragab, A. and Sakr, M. (2018) Factors Influencing Credit Decision for Lending SMEs: A Case Study on National Bank of Egypt. Open Access Library Journal, 5, e4996.

[6] IFC (2013) International Finance Corporation. Closing the Credit Gap for Formal and Informal Micro, Small, and Medium Enterprises. https://openknowledge.worldbank.org/handle/10986/21728

[7] St-Pierre, J., Foleu, L., Abdulnour, G., Nomo, S. and Fouda, M. (2015) Small Medium Enterprise Development Challenges in Cameroon: An Entrepreneurial Ecosystem Perspective. Transnational Corporations Review, 7, 441-462. https://doi.org/10.5148/tncr.2015.7405

[8] Mutoko, W. and Kapunda, M. (2017) Factors Influencing Small Medium and Micro-Sized Enterprises Borrowing from Banks: The Case of the Botswana Manufacturing Sector. Independent Research Journal in the Management Sciences, 17, Article No. a426. https://doi.org/10.4102/ac.v17i1.426

[9] Hammer, A., Jabara, C., Cardenas, E. and Wise, J. (2010) Small and Medium-Sized 
Enterprises: Overview of Participation in U.S. Exports. Investigation No. 332-508, United States International Trade Commission, Washington DC. https://usitc.gov/publications/332/pub4125.pdf

[10] United Nations Economic and Social Commission for Asia and the Pacific (2012) Contributions, Challenges and Prospects of SMEs.

https://www.unescap.org/sites/default/files/8\%20-\%20II.\%20Contributions\%2C\%20 challenges\%20and\%20prospects\%20of\%20SMEs.pdf

[11] World Bank (2013) Competitive Small and Medium Size Enterprises: A Diagnostic to Help Design Smart SME Policies. https://openknowledge.worldbank.org/handle/10986/16636

[12] Mukete, B., Sun, Y., Etongo, D., Sajjad, S., Ngoe, M. and Tamungang, R. (2018) Cameroon Must Focus on SDGs in Its Economic Development Plans. Environment: Science and Policy for Sustainable Development, 60, 25-32. https://doi.org/10.1080/00139157.2018.1419008

[13] Isoh, A., Joelle, M. and Esowe, S. (2020) Modeling Critical Survival Factors of Small and Medium Size Enterprises in Cameroon. International Journal of Science and Business, 4, 201-212.

[14] Nkuah, K., Tanyeh, J. and Gaeten, K. (2013) Financing Small and Medium Enterprises in Ghana: Challenges and Determinants in Accessing Bank Credit. International Journal of Research in Social Sciences, 2, 12-25.

[15] Fatoki, O. (2014) The Causes of the Failure of New Small and Medium Enterprises in South Africa. Mediterranean Journal of Social Science, 5, 922-927.

[16] Evans, O., Josephine, P. and Yeboah, O. (2015) Challenges Faced by SMES in Accessing Credit in Tamale. Global Journal of Commerce and Management Perspective, 4, 32-39.

[17] World Bank (2015) Small and Medium Enterprises (SMEs) Finance, Improving: SMEs' Access to Finance and Finding Innovative Solutions to Unlock Sources of Capital. http://www.worldbank.org/en/topic/smefinance

[18] Piabuo, S., Baye, F. and Tieguhong, J. (2015) Effects of Credit Constraints on the Productivity of Small and Medium-Sized Enterprises in Cameroon. Journal of Economics and International Finance, 7, 204-212. https://doi.org/10.5897/JEIF2015.0688

[19] Chowdhury, M. and Alam, Z. (2017) Factors Affecting Access to Finance of Small and Medium Enterprises of Bangladesh. USV Annals of Economics and Public Administration, 2, 55-68.

[20] Kira, A. and He, Z. (2012) The Impact of Firm Characteristics in Accessing Finance by Small and Medium-Sized Enterprises in Tanzania. International Journal of Business and Management, 7, 108-119. https://doi.org/10.5539/ijbm.v7n24p108

[21] World Bank (2012) Doing Business 2012: Doing Business in a More Transparent World. World Bank, Washington DC.

https://openknowledge.worldbank.org/handle/10986/5907

[22] Vera, D. and Onji, K. (2010) Changes in the Banking System and Small Business Lending. Small Business Economics, 34, 293-308. https://doi.org/10.1007/s11187-008-9119-9

[23] Fatoki, O. and Asha, F. (2011) The Impact of Firm and Entrepreneurial Characteristics on Access to Debt Finance by SMEs in King Williams' Town, South Africa. International Journal of Business and Management, 6, 170-179. https://doi.org/10.5539/ijbm.v6n8p170

[24] Subeyr, M. and Muturi, W. (2017) Factors Affecting Access to Credit by Microen- 
terprises in Garowe, Puntland. International Journal of Economics, Commerce and Management, 3, 291-311.

[25] Osano, H. and Languitone, H. (2016) Factors Influencing Access to Finance by SMEs in Mozambique: Case of SMEs in Maputo Central Business District. Journal of Innovation and Entrepreneurship, 5, Article No. 13.

https://doi.org/10.1186/s13731-016-0041-0

[26] Kamdem, U. (2019) Reducing the Financial Gap between the Banking Sector and SMEs in Cameroon: What Role for Crowdfunding and Business Angels? 53rd International Business Research Conference, Melbourne, 21-22 November 2019, 1-5.

[27] Mbangari, K., Fouepe, G. and Fonteh, M. (2019) Role of Farmer Organizations in Resource Mobilization in Mezam Division, Cameroon. International Journal of Development Research, 9, 31808-31816.

[28] Fogwe, Z. (2020) Biking Acculturation Incidence on the Cameroon Urban Activity Fluxes: A Traffic Congestion Panacea or Palliative in Bamenda? International Journal of Global Sustainability, 4, 40-54. https://doi.org/10.5296/ijgs.v4i1.16517

[29] Mukete, B., Sun, Y., Ayonghe, S., Ojong, L., Itoe, C. and Tamungang, R. (2017) Adaptation of Women to Climate Variability in the Southern Slopes of the Rumpi Hills of Cameroon. Agriculture, Forestry and Fisheries, 5, 272-279. https://doi.org/10.11648/j.aff.20160506.19

[30] Olayiwola, M., Eludoyin, O. and Ekecha, E. (2011) Land Use Change in the Mezam division of the North West Province, Cameroon from Landsat Imageries (1988 and 2001). Ethiopian Journal of Environmental Studies and Management, 4, 49-55. https://doi.org/10.4314/ejesm.v4i1.6

[31] Mukete, B., Sun, Y., Etongo, D., Ekoungoulou, R., Folega, F., Sajjad, S., Ngoe, M. and Ndiaye, G. (2018) Household Characteristics and Forest Resources Dependence in the Rumpi Hills of Cameroon. Applied Ecology and Environmental Research, 16, 2755-2779. https://doi.org/10.15666/aeer/1603 27552779

[32] Mukete, B., Sun, Y., Zama, E. and Monono, S. (2016) Paper Consumption and Environmental Impact in an Emerging Economy. Journal of Energy, Environmental and Chemical Engineering, 1, 13-18.

[33] Greene, W. (2018) Econometric Analysis. 8th Edition, Pearson Education Limited, London.

[34] Okurut, N., Olalekan, Y. and Mangadi, K. (2011) Credit Rationing and SME Development in Botswana: Implications for Economic Diversification. Botswana Journal of Economics, 8, 62-85.

[35] Haron, H., Said, B., Jayaraman, K. and Ismail, I. (2013) Factors Influencing Small Medium Enterprises (SMES) in Obtaining Loan. International Journal of Business and Social Science, 4, 182-195. 